\title{
Meningitis Simultaneuously Due to Cryptococcus neoformans and Mycobacterium tuberculosis in a Inmunosupressed Patient
}

\section{Sergio Castaño*, Noemi Legaristi, Alejandro Martín and Ana Tejero Mogena}

Intensive Care Department, Araba University Hospital, C/ Olaguibel, 2901004 Vitoria, Spain

\begin{abstract}
A 51-year-old white female patient was admitted to our Intensive Care Unit, who was originally referred from Nephrology department due to neurological impairment. She had crhonic renal failure and was being treated with immunosuppressants (tacrolimus and prednisone) because she had undergone a cadaveric kidney transplantation in the past. The previous week she had been discharged after being treated for tuberculosis but she developed new symtoms including nausea, vomiting and hepatotoxicity due to the antituberculous treatment, which had to be finally stopped. Her abdominal simptomatology improved, however, she developed neurological impairment, refractory headache and tremors. On admission her temperature was $37.5^{\circ} \mathrm{C}$ and Glasgow coma score 13.
\end{abstract}

Keywords: Tuberculosis meningitis; Cryptococcal meningitis

\section{Case Summary}

A 51-year-old white female patient was admitted to our Intensive Care Unit, who was originally referred from Nephrology department due to neurological impairment. She had crhonic renal failure and was being treated with immunosuppressants (tacrolimus and prednisone) because she had undergone a cadaveric kidney transplantation in the past. The previous week she had been discharged after being treated for tuberculosis but she developed new symtoms including nausea, vomiting and hepatotoxicity due to the antituberculous treatment, which had to be finally stopped. Her abdominal simptomatology improved, however, she developed neurological impairment, refractory headache and tremors. On admission her temperature was $37.5^{\circ} \mathrm{C}$ and Glasgow coma score 13. Blood samples were obtained and analysed (Table 1). A cranial CT scan was performed that reported: enlarged ventricles without midline shift. An external ventricular drain was placed and clear CSF obtained with an opening pressure of $18 \mathrm{~mm}$ $\mathrm{Hg}$; these measures improved the headache. After checking CSF tests (Table 1) the presumptive diagnosis was meningitis. Treatment with ceftriaxone, ampicillin, linezolid and acyclovir was started. Antigen detection for Streptococcus pneumoniae in CSF and urine was negative as herpesviridae polymerase chain reaction test.

The patient's clinical situation worsened. New sets of CSF were analysed biochemically and the results showed lymphocytic pleocytosis, raised CSF protein and reduced CSF glucose (Table 1). After checking the improvement of the liver function, treatment against mycobacterium tuberculosis was reintroduced. The CSF culture test isolated Cryptococcus neoformans, and treatment with liposomal amphotericin B and flucytosine was started. Our patient developed intracranial hypertension and required addition of several drugs, tyophental included. Two weeks later, antifungal therapy was replaced and fluconazole was started. After an initial improvement, the patient suffered from several systemic complications, including septic shock, external ventricular drainage related Serratia sp meningitis and intracranial hypertension which finally resulted in the death of the patient 49 days after admission-

\section{Discussion}

The incidence of infections Caused by Cryptococcus neoformans has increased over the past 20 years as a result of Human Inmunodeficiency Virus epidemic and the raise of inmunosuppressive therapies. It

\begin{tabular}{|l|l|l|}
\hline Blood tests & $\mathbf{1}^{\text {st }}$ CSF tests & $\mathbf{2}^{\text {nd }}$ CSF tests \\
\hline Creatinine $4 \mathrm{mg} / \mathrm{dL}$ & Glucose $44 \mathrm{mg} / \mathrm{dL}$ & Glucose $60 \mathrm{mg} / \mathrm{dL}$ \\
\hline Urea $73 \mathrm{mg} / \mathrm{dL}$ & Total protein $167.1 \mathrm{mg} / \mathrm{dL}$ & Total protein $152 \mathrm{mg} / \mathrm{dL}$ \\
\hline AST $69 \mathrm{U} / \mathrm{L}$ & ADA $5 \mathrm{U} / \mathrm{L}$ & ADA $15 \mathrm{U} / \mathrm{L}$ \\
\hline ALT $396 \mathrm{U} / \mathrm{L}$ & Red cell count 12/cumm & Red cell count $7 /$ cumm \\
\hline White blood cell count & $\begin{array}{l}\text { White cell count 126/ } \\
\text { cumm (18\% lymphocytes, } \\
\text { 14900/cumm }\end{array}$ & $\begin{array}{l}\text { White cell count } 100 / \\
\text { cumm }(65 \% \text { lymphocytes, } \\
\text { 35\% neutrophils) }\end{array}$ \\
\hline
\end{tabular}

Table 1: Blood and CSF tests analysis.

predominates in male patients, and is uncommon in immunocompetent patients $[1,2]$.

The upper respiratory tract is the gateway for these infections in most cases; in the socket, the fungus can cause an inflammatory process that can be completely asymptomatic or can produce mild respiratory symptoms. A weak cellular inmune response allows the fungus to spread trough the systemic circulation and disseminates to the brain [3].

The insidious clinical signs are difficult to diagnose. It should be suspected in any immunocompromised patient who presents fever and signs/symptoms related to cerebral nervous system. The simptomatology is variable, some patients have symptoms several months before the diagnosis, while others have an acute illness for only a few days. The subacute or chronic onset is more frequent and it includes headache, fever, chills, personality changes and memory leak. It usually occurs in patients that have risk factors for acquiring the infection [4]. Clinically, according to some published series, headache occurs in $100 \%$ of patients, and neurological impairment, meningeal signs, and involvement of cranial nerves in $22 \%$, being $27 \%$ of mortality rate. Lumbar puncture is required for diagnosis, with CSF usually

*Corresponding author: Sergio Castaño, Intensive Care Department, Araba University Hospital, C/ Olaguibel, 2901004 Vitoria, Spain, Tel: +34-945007652; E-mail: sergio.castanoavila@osakidetza.net

Received May 28, 2015; Accepted June 27, 2015; Published July 04, 2015

Citation: Castaño S, Legaristi N. Martín A, Mogena AT (2015) Meningitis Simultaneuously Due to Cryptococcus neoformans and Mycobacterium tuberculosis in a Inmunosupressed Patient. Brain Disord Ther S2: 002. doi:10.4172/2168-975X. S2-002

Copyright: (c) 2015 Castaño S, et al. This is an open-access article distributed under the terms of the Creative Commons Attribution License, which permits unrestricted use, distribution, and reproduction in any medium, provided the original author and source are credited. 
Citation: Castaño S, Legaristi N. Martín A, Mogena AT (2015) Meningitis Simultaneuously Due to Cryptococcus neoformans and Mycobacterium tuberculosis in a Inmunosupressed Patient. Brain Disord Ther S2: 002. doi:10.4172/2168-975X.S2-002

showing a moderate increase of the opening pressure; most patients have CSF lymphocytic pleocytosis (>100 cells $/ \mathrm{mL}$ ), moderate increase of CSF protein levels, and glucose consumption [5]. CSF analysis with India ink staining allows diagnosis of $50 \%$ of patients (HIV sensitivity is 75\%) [5] and cryptococcal antigen test on CSF suggests the presence of cryptococcal infection before the culture tests are completed. The diagnosis is definitively established by culturing the microorganism in the cerebrospinal fluid [5]; it is also the most sensitive tool to asses treatment response with an average growing time of 3-4 days for yeasts.

Intracranial hypertension with or without multifactorial hydrocephalus is one of the complications that can occur, and it sometimes requires external ventricular drainage [6]. It is important to consider that after treatment, the India ink staining test can persist positive for up to two years, in spite of CSF cultures being negative [7].

Mycobacterial cultures can result in delay of the diagnostic and, considering the seriousness of subacute/chronic meningitis, the empirical treatment should focus on those microorganisms that are more frecuently related to these kind of infections. Rapid diagnostic tests can aid the choice of the right treatment for the condition. Tuberculous meningitis and fungal infections of central nervous system are difficult to differentiate because of the cytobiochemical CSF tests and clinical signs being very similar. For the differential diagnosis, latex tests for identifying antigens discussed above are very helpful. In patients with tuberculous meningitis the polymerase chain reaction test is more sensitive than the microscopic test and the culture. We must not forget the adenosine deaminase (ADA) enzyme which is associated with diseases that produce a cellular immune response; its determination may be helpful for the diagnosis of TB meningitis. The sensitivity and specificity of CSF culture in tuberculous meningitis and cryptococcal meningitis increase by repeating cultures of large volumes (up to $25 \mathrm{ml}$ ) of CSF [8].

Treatment should include antifungal therapy, measures for the management of ICP and reduction of immunosuppressive therapy. In contrast to the the antifungal treatment, the induction therapy differs: liposomal amphotericin B + flucytosine (2 weeks), consolidation therapy: fluconazole ( 8 weeks) and maintenance therapy: fluconazole (6-12 months) $[9,10]$.

There are few publications that address co-infection cases of cryptococcal and tuberculosis in the central nervous system. The possibility of co-infection of the central nervous system must be considered if the evolution is unfavorable [11].

\section{Conclusion}

Considering the facts presented in our case report, our recommendation is to consider empirical cryptococcal meningoencephalitis treatment until the microbiological findings for immunocompromised patients that develop subacute meningitis with mononuclear pleocytosis, raised protein levels and glucose consumption in CSF analysis are available. The serological CSF latex test is very sensitive for the diagnosis, it is quick and easy to interpret and could be very useful when choosing the most appropriate empirical treatment.

\section{References}

1. Gaona-Flores VA (2013) Central nervous system and Cryptococcus neoformans. N Am J Med Sci 5: 492-493.

2. Shinjoh M, Miyairi I, Sakurai M, Takahashi M, Ariyasu D, et al. (2005) Cryptococcal meningitis in an immunocompetent child. Eur J Pediatr 164: 596-597.

3. Vázquez TO, Martínez BI, Campos RT (2005) Criptococosis. Historia natural y estado actual del tratamiento. Acta Pediatr Mex 26: 18-28.

4. Cox GM, Perfect JR, Kauffman CA, Thorner AR (2013) Clinical manifestation and diagnosis of Cryptococcus neoformans meningoencephalitis in HIV seronegative patients. UpToDate.

5. Arias BG, Montero LAZ (2011) Meningeal cryptococcosis: clinical and laboratory Characteristics. Acta Neurol Colomb 27: 9-27.

6. Guevara-Campos J, González-Guevara L, Urbéz-Cano J, Fermín S (2009) Cryptococcus neoformans meningoencephalitis in immunocompetent schoolchildren. Invest Clin 50: 231-239.

7. Tjia TL, Yeow YK, Tan CB (1985) Cryptococcal meningitis. J Neurol Neurosurg Psychiatry 48: 853-858.

8. Codina MG, De Cueto M, Echevarria JE, Vicente D, Prats G (2010) Microbiological diagnosis of central nervous system infections. Enfermedades infecciosas y microbiología clínicas 29: 20-400.

9. Perfect JR, Dismukes WE, Dromer F, Goldman DL, Graybill JR, et al. (2010) Clinical practice guidelines for the management of cryptococcal disease: 2010 update by the infectious diseases society of america. Clin Infect Dis 50: 291322.

10. Cox GM, Perfect JR, Kauffman CA, Thorner AR, Kaplan SL (2013) Treatment of Cryptococcus neoformans meningoencephalitis and disseminated infection in HIV seronegative patients. UpToDate.

11. Cánovas DG, Araújo SB, Díaz RB, Fontanillas JR (2009) Association of tuberculous meningitis and cryptococcal meningitis in HIV-infected patient Med Clin (Barc) 133: 360-362.
This article was originally published in a special issue, Cdk5 and Brain Disorders handled by Editor(s). Dr. Jyotshnabala Kanungo, National Center for Toxicological Research, USA
Submit your next manuscript and get advantages of OMICS Group submissions

Unique features:

User friendly/feasible website-translation of your paper to 50 world's leading languages Audio Version of published paper

Digital articles to share and explore

Special features:

- 200 Open Access Journals

15,000 editorial team

21 days rapid review proces

Quality and quick editorial, review and publication processing

Indexing at PubMed (partial), Scopus, DOAJ, EBSCO, Index Copernicus and Google Scholar etc Sharing Option: Social Networking Enabled

Authors, Reviewers and Editors rewarded with online Scientific Credits

Better discount for your subsequent articles

Submit your manuscript at: http://www.omicsonline.org/submission 